3. Horova K.O. (2014) Vyznachennia osnovnykh pidkhodiv do klasyfikatsii autsorsynhu na suchasnomu etapi ekonomichnoho rozvytku [Identification of the main approaches to the classification of outsourcing at the current stage of economic development]. Ekonomichnyi analiz : zbirnyk naukovykh prats - Economic analysis: a collection of scientific works. 18(1). 12-19. (in Ukrainian)

4. Gottshtal`k P., Solli-Seter Kh. (2007). IT-autsorsing: postroenie vzaimovy`godnogo sotrudnichestva [IT outsourcing: building mutually beneficial cooperation]. Moscow: Alpina Business Books. (in Russian)

5. Dykan O.V., Biletska D.O., Afonina T.S. (2018). Metodolohichni aspekty autsorsynhu [Methodological aspects of outsourcing]. Visnyk ekonomiky transportu i promyslovosti - Bulletin of Economics of Transport and Industry. 64. 24-31. (in Ukrainian)

6. Labzhaniia R.H. (2013) Mistse i rol autsorsynhu v sferi posluh i vyrobnytstvi [The place and role of outsourcing in the field of services and production]. Biznes Inform - Business Inform, 7. 357-361. (in Ukrainian)

7. Mikhajlov D.M. (2009). Autsorsing. Novaya sistema organizaczii biznesa [Outsourcing. New business organization system]. Moscow: Knorus. (in Russian)

8. Official website of the International Institute of Outsourcing. Retrieved from: http://www.outsourcing.com/ (in Ukrainian)

9. Susidenko V.T., Tanasiichuk O.M., Zharlinska R.H. (2010). Pryntsyp pobudovy dohovirnykh kanaliv rozpovsiudzhennia na pryntsypakh autsorsynhu [The principle of encouraging negotiated channels in rozpovsjuzhennya on the principles of outsourcing]. Visnyk Khmelnytskoho natsionalnoho universytetu - Newsletter of the Khmelnitsky National University. 5(1). 41-45. (in Ukrainian)

10. Ukraine ranks first in Europe in the field of IT outsourcing: online publication. Retrieved from: 10. Ukraine ranks first in Europe in the field of IT outsourcing: online publication. Retrieved from:

11. Khejvud Dzh. B. (2004). Autsorsing v poiskakh konkurentnikh preimushestv [Outsourcing in Search of Competitive Advantage]. Moscow: Publishing House "Williams". (in Russian)

Рецензент д.е.н., професор Маркіна I.A.

УДК: 339.9.012.421

Савіцький А.В., к.е.н., доцент

Хмельницький політехнічний коледж національного університету «Львівська політехніка»

\title{
ФАКТОРИ ВНУТРІШНЬОГО ТА ЗОВНІШНЬОГО СЕРЕДОВИЩА В СИСТЕМІ ОРГАНІЗАЦІЙНО-ЕКОНОМІЧНОГО МЕХАНІЗМУ УПРАВЛІННЯ ПРИБУТКОВІСТЮ ЕКСПОРТООРІЕНТОВАНОГО ПІДПРИЕМСТВА
}

У статті досліджено особливості впливу економічних факторів на прийняття управлінських рішень щодо підвищення прибутковості експортоорієнтованого підприємства. Обгрунтовано значення запуску організаційноекономічного механізму управління у структурі зовнішніх і внутрішніх факторів впливу на формування прибутковості. Виділено групову класифікацію економічних факторів та охарактеризовано їх рівні прояву в системі інституційної, господарської та виробничої підсистем управління. Наведено стадії трансформації та визначення ступеня важливості факторів за допомогою накопичення, відсіювання, аналізу та оцінки інтенсифікації дії. Представлено схему формування рівнів прояву впливу економічних факторів зі сторони інтегрованості елементів двох систем управління експортоорієнтованим підприємством: організаційноекономічного механізму та системи прибутковості.

Ключові слова: економічні фактори, прибутковість, організаційно-економічний механізм управління, управлінське рішення, експортоорієнтованість.

Savitskyi A.

\section{FACTORS OF INTERNAL AND EXTERNAL ENVIRONMENT IN THE SYSTEM OF ORGANIZATION AND ECONOMIC MECHANISM OF MANAGING THE PROFITABILITY OF EXPORT-ORIENTED ENTERPRISE}

The article is devoted to the research of peculiarities of economic factors influence on the management decision making in order to increase the profitability of an export-oriented enterprise. There was interpreted the importance of organizational and economic management mechanism launching in the structure of external and internal factors of influence on profitability formation. There were emphasized few main groups of economic factors classification and characterized their levels of representing in the system of institutional, economic and production subsystems of management. There were researched the stages of transformation and determination of the degree of factors importance through accumulation, screening, analysis and activity intensification evaluation. There was build the scheme of formation that concerns representation of levels of economic factors influence from the side of integrated elements of two export-oriented enterprise's management systems: organizational-economic mechanism and profitability system.

Keywords: economic factors, profitability, organizational and economic mechanism of management, management decision, export orientation.

Савицкий А.В. 


\section{ФАКТОРЫ ВНУТРЕННЕЙ И ВНЕШНЕЙ СРЕДЫ В СИСТЕМЕ ОРГАНИЗАЦИОННО-ЭКОНОМИЧЕСКОГО МЕХАНИЗМА УПРАВЛЕНИЯ ПРИБЫЛЬНОСТЬЮ ЭКСПОРТООРИЕНТИРОВАНОГО ПРЕДПРИЯТИЯ}

В статье исследованы особенности влияния экономических факторов на принятие управленческих решений по повышению прибыльности экспортоориентированного предприятия. Обосновано значение запуска организационно-экономического механизма управления в структуре внешних и внутренних факторов влияния на формирование доходности. Выделено групповую классификацию экономических факторов и охарактеризованы их уровни проявления в системе институциональной, хозяйственной и производственной подсистем управления. Приведены стадии трансформации и определения степени важности факторов с помощью накопления, отсева, анализа и оценки интенсификации действия. Представлена схема формирования уровней проявления влияния экономических факторов со стороны интегрированности элементов двух систем управления экспортоориентированным предприятием: организационно-экономического механизма и системы прибыльности. управления.

Ключевые слова: экономические факторы, доходность, организационно-экономический механизм

Постановка проблеми у загальному вигляді i iï зв'язок 3 важливими науковими та практичними завданнями. Посилення інтеграційних процесів, приналежність України до СОТ та функціонування в рамках Зони вільної торгівлі спричиняє нові зміни на усіх рівнях соціально-економічного розвитку та суспільного відтворення. Не виключенням і $є$ діяльність вітчизняних промислових підприємств, особливо тих, які активно співпрацюють із контрагентами зовнішнього ринку. Для того, щоб максимізувати віддачу від виробництва продукції на експорт, промислові виробники повинні приділяти достатньо уваги дослідженню умов впливу економічних факторів у структурі запуску їх організаційно-економічного механізму управління. В першу чергу, це пов'язано із потребою адаптації діяльності підприємства до сучасних вимог ринку, які значно ускладнюють можливості отримання прибутку та підвищення загального рівня прибутковості.

Аналіз останніх досліджень, у яких започатковано вирішення проблеми. Проблемам визначення впливу факторів на економічну діяльність підприємства, управління прибутковістю та посилення інтеграційних процесів присвячено значку кількість наукових праць таких вчених, економістів та дослідників як: Бараннік I.О., Васильківський Д.М., Герасимов А.А., Добикіна О.К., Довгань Л.Є., Дудукало Г.О., Заболотний Г.М., Калетнік Г.М., Карачина Н.П., Касьянюк С.В., Кендюхов О.В., Козловський С.В., Кокотько М.Є., Костенко Т.Д., Краснокутська Н.С., Назаров Н.К., Паламарчук О.М., Рижиков В.С. та ін.

Цілі статті. Основні цілі статті полягають в обгрунтуванні класифікаційних особливостей груп економічних факторів впливу на прийняття управлінських рішень щодо підвищення прибутковості експортоорієнтованого підприємства.

Виклад основного матеріалу дослідження 3 повним обгрунтуванням отриманих наукових результатів. На сьогодні, економічна поведінка підприємства в повній мірі підлягає адаптації під умови ринку та змінюється на основі управлінських підходів його керівного апарату, що залежать від економічних факторів впливу. Через те, обсяг вхідної інформації, яка надходить із внутрішнього і зовнішнього середовища, а також, дані попередніх періодів включають умови та фактори функціонування підприємства. Аналіз та оцінка такої інформації дасть змогу визначити найбільш пріоритетні фактори впливу, які стосуються лише економічної складової діяльності підприємства. Надалі, адміністрація та менеджмент повинні узгодити цілі стратегій із реальним потенціалом виробництва продукції на експорт та управління прибутковістю, врахувати поточні і актуальні змінні, здійснити коригування економічної поведінки згідно нових умов виробництва [4, с.158].

В науковій літературі вчені та дослідники зупиняються на важливості трьох базових систем запуску організаційно-економічного механізму: забезпечення, функціональної та цільової. Керуючись тим, що в основу системи забезпечення покладено правову, ресурсну, нормативно-законодавчу, наукову, технічну та інформаційну підсистеми, а процес управління базується на функціях планування, організації, мотивації, контролю та регулювання [2; 9, с.73], структура економічних 
факторів буде варіюватись в залежності від змісту завдань, які реалізовуються на рівні вищенаведених складових. На авторське бачення, відповідно до того, який етап алгоритму прийняття управлінських рішень організаційно-економічного механізму буде активовано, змістовність тих чи інших факторів внутрішнього і зовнішнього середовища підприємства підлягатиме до розгляду і оцінці. В додаток, зазначимо, що процес управління прибутковістю бере свій початок від визначення цілей організаційноекономічного механізму, сутність яких повинна покладатись на критерії досягнення кращих фінансових результатів.

Якщо звернути увагу на етапність запуску організаційно-економічного механізму зі сторони використання можливостей експортоорієнтованості у підвищенні прибутковості підприємства на основі урахування дії економічних факторів впливу, обгрунтуємо наступні:

1. Прийняття рішень про цілі досягнення запланованого рівня прибутку за допомогою запуску циклу виробництва продукції на експорт (цільова система).

2. Визначення показників які, будуть характеризувати процеси продукування та досягнення прибутковості (функціональна система).

3. Порівняння, аналіз та оцінка фактичних показників із плановими, нормативними та у динаміці попередніх періодів (система забезпечення, функціональна та цільова системи).

4. Ухвалення управлінських рішень щодо прийнятності досягнутих результатів та розробка заходів у напрямі коригування організаційно-виробничої діяльності у подальших періодах (система забезпечення, функціональна система).

5. Розмежування та впровадження заходів коригування відхилень в межах організації виробництва, ЗЕД, отримання планового прибутку і підвищення прибутковості (система забезпечення, функціональна та цільова системи).

6. Оцінка реалізації заходів коригування та формування стратегії перспектив підвищення прибутковості, управління експортоорієнтованістю та ЗЕД (цільова система) $[9$, c.73].

На авторський погляд, на кожний 3 етапів запуску організаційно-економічного механізму управління підприємством впливають різні економічні фактори, які за своєю сутністю повинні відображати їх результативність. Якщо вчасно та достовірно здійснити оцінку економічних факторів впливу на перший, другий та третій етапи, заходи коригування діяльності щодо формування прибутковості та організації експортних операцій будуть мінімізовані. В свою чергу, це дасть змогу перейти на новий виробничий цикл, дозволить вивільнити час, обмежить загальні та змінні витрати, сприятиме досяганню балансу роботи між плануванням і результатами. 3 огляду на це, зазначимо, що економічні групи факторів внутрішнього середовища підприємства здатні впливати на функціональну систему, зовнішнього - систему забезпечення. Впливу факторів обох середовищ підлягає цільова система. На авторську думку, найбільш суттєвими групами економічних факторів слід розуміти наступні:

1. Група факторів нормативного планування та технічних регламентів, яка сприяє визначенню критеріїв виробництва та управління.

2. Група факторів продуктивності етапів виробничого процесу, яка дозволяє систематизувати показники для аналізу, оцінки, коригування і контролю.

3. Група факторів фінансової стабілізації підприємства, яка дасть змогу удосконалити організацію продукування на засадах досягнення прогресивних економічних норм та оптимізації витрат.

Для того, щоб підсумувати вищевикладене, додамо, що на думку, Довгань Л.С. та Дудки Г.О., ефект від управління в структурі організаційно-економічного механізму підприємства полягає у формуванні його здатності до адаптивності і гнучкості забезпечувати досягнення прибутковості та посилення тривалості розвитку відповідно до обраних перед цим стратегій [2].

Через те, основним завданням, яке стоїть перед керівниками експортоорієнтованих підприємств є раціональне акумулювання та повне завантаження їх наявних ресурсів для формування інтегрованого економічного, експортного та прибуткового потенціалів господарювання. Оскільки, велику роль у зазначених процесах покладено на урахування 
впливу економічних факторів, необхідно виділити і те, що на думку Козловського С.В, сучасна економічна система має відображати здатність підвищувати свою активність через власні і залучені економічні ресурси з урахуванням можливостей, умов їх поповнення та ефективного використання [6, с.55].

Виходячи 3 того, що структура економічного потенціалу функціонує на трьох основних рівнях управління (інституційний, господарський та виробничий) [1, с.29, 142-143; 3; 6, с.5556; 7, с.28-29; 10, с.29-31] і пов'язана з різною наповненістю складових та елементів, процес рівнів формування економічних факторів, доцільно розуміти зі сторони специфіки той чи іншої структуроутворюючої одиниці у цільовій системі менеджменту підприємства.

Якщо звернути увагу на урахування важливості експортної орієнтованості підприємства, Назаров Н.К. та Бараннік І.О. спочатку виділяють об'єкти управління потенціалу (об'єкти формування, використання та розвитку), і лише в подальшому обгрунтовують види управління ними: виробниче, організаційне та економічне [8, с.145].

На авторське бачення, економічні фактори мають здатність до прояву як на найнижчому, середньому, так і найвищому рівнях управління.

Згідно досліджень Добикіної В.С., Рижикова С.В., Касьянюк М.Є., Кокотько Т.Д., Костенко А.А., Герасимова А.А., Козловського С.В., Калетніка Г.М., Заболотного Г.М., Васильківського Д.М., Краснокутської Н.С. та Кендюхова О.В., необхідно обгрунтувати наступне [1, с.29, 142-143; 5, с.10; 6, с.55-56; 10, с.29-31]:

1. Найвищий рівень формування прояву впливу економічних факторів базується на активізації інноваційного, інтелектуального, фінансового та управлінського потенціалів підприємства, в рамках яких здійснюється планування організації виробництва продукції на експорт та розраховуються обсяги бажаного прибутку. На даному етапі формується загальне бачення того, які є можливості у підприємства стосовно величини залучення витрат та потреби у додаткових інноваційних розробках, залученні ресурсів, інвестицій.

2. Середній рівень формування прояву впливу економічних факторів включає активізацію маркетингового, виробничого та організаційного потенціалів підприємства, оскільки пов'язаний із дослідженнями можливостей ринку, замовленням та постачанням належних матеріалів і сировини, формуванням виробничих планів, термінів виконання, розподілом обов'язків.

3. Найнижчий рівень формування прояву впливу економічних факторів базується на здійснені безпосередньої роботи щодо розгортання етапів виробничого процесу, його складності, завершеності та контролю. На даному рівні активізується організаційний, виробничий, трудовий, ресурсний, техніко-технологічний та інформаційний потенціали.

3 огляду на вищесказане, зазначимо, що разом із функціонуванням трьох рівнів управління економічні фактори підлягають проходженню декількох стадій трансформації та визначення ступеня їх важливості за допомогою накопичення, відсіювання, аналізу та оцінки інтенсифікації дії:

1. Стадія розробки та планування виробництва продукції на внутрішній і зовнішній ринки (інституційний рівень).

2. Стадія початку виконання та підготовки (інституційний та господарський рівні).

3. Реалізація завдання у процесі розгортання окремих етапів продукування та створення взаємозв'язку в співвідношенні досягнення якості покладених функцій на керівників i підлеглих (виробничий та господарський рівні).

4. Завершення виробництва (виробничий та господарський рівні).

5. Контроль над виконанням плану (інституційний та господарський рівні).

На рис.1 представлено схему формування рівнів прояву впливу економічних факторів зі сторони інтегрованості елементів двох систем управління експортоорієнтованим підприємством: організаційно-економічного механізму та системи прибутковості. В даному випадку, акцентується рівномірна увага як на активізації процесів управління, так і посилення дій щодо підвищення можливостей отримання підприємством вищого прибутку від реалізації продукції на закордонному ринку. 


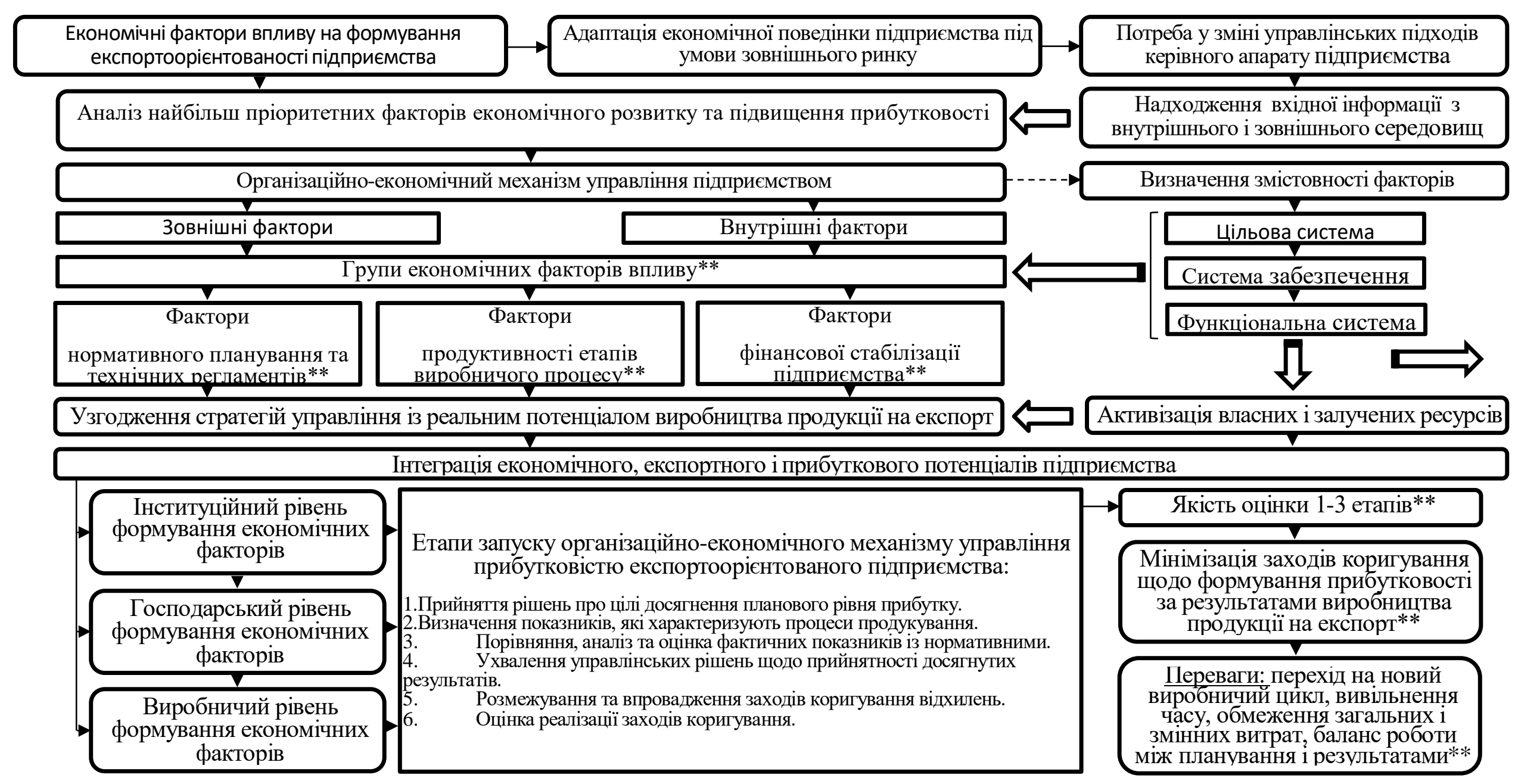

Рис.1 Рівні прояву впливу економічних факторів в системі організаційно-економічного механізму управління експортоорієнтованим підприємством та його прибутковості*, **

*систематизовано та обгрунтовано автором на основі: [1, с. $29,142-143 ; 2 ; 3 ; 4$, с.10; 5, с.55-56; 6, с.28-29; 7, с.145; 8, с.73; 9, с.29-31]

**запропоновано автором 
Висновки. Отже, вище наведені дослідження показують, що ключовим моментом, на якому починають запускатися процеси факторного навантаження $\epsilon$ виникнення потреби у адаптації економічної поведінки суб'єкта господарювання до ринкових умов, інтеграції, а також, роботи за правилами ЗВТ + . Керуючись цим, саме у структурі економічного потенціалу, підприємство може визначити, які фактори впливу є основними, другорядними та тими, які визначають його подальшу прибуткову діяльність. Надалі, для керівника підприємства важливо вміти правильно оцінити ситуацію щодо використання інформації про зовнішнє та внутрішнє середовища для досягнення балансу між запланованим та майбутніми фінансовими результатами.

\section{Список бібліографічного опису:}

1.Васильківський Д.М. Підвищення економічного потенціалу підприємства: теорія, методи, практика : монографія / Д.М. Васильківський. - Хмельницький : ХНУ, 2014. - 226 с.

2.Довгань Л.Є. Формування організаційно-економічного механізму ефективного управління підприємством / Л.Є. Довгань, Г.О. Дудукало // [Електронний ресурс]. - Режим доступу: http://ela.kpi.ua/bitstream/123456789/2986/1/41.pdf.

3.Калетнік Г.М. Інноваційні моделі управління стратегічним економічним потенціалом сучасних економічних систем / Г.М.Калетнік, Г.М. Заболотний, С.В. Козловський // [Електронний ресурс]. - Режим доступу: https://www.researchgate.net/profile/Serhii_Kozlovskyi/publication/298002657_Innovative_models_of_strategic_economic_potential_ management_within_contemporary_economic_systems/links/5ca72b314585157bd3235acf/Innovative-models-of-strategic-economicpotential-management-within-contemporary-economic-systems.pdf.

4.Карачина Н.П. Економічна поведінка машинобудівних підприємств: теорія, методологія, практика управління : монографія / Н.П. Карачина. - Вінниця : Книга - Вега, 2010. - 416 с.

5.Кендюхов О.В. Організаційно-економічний механізм управління інтелектуальним капіталом підприємства: автореф. дис. на здобугтя наук. ступеня док. ек. наук : спец. 08.00 .04 «Економіка та управління підприємствами (переробна промисловість)» / О.В. Кендюхов. - Донецьк, 2007. - 31 с.

6.Козловський С.В. Роль стратегічного економічного потенціалу в управлінні факторами розвитку сучасних економічних систем / С.В. Козловський // Економіка та держава. - 2010. - №2. - С.55-58.

7. Краснокугська Н.С. Потенціал підприємства: формування та оцінка: Навчальний посібник. - Харків. - 2004. - 289 с. 8. Назаров Н.К. Економічна безпека експортно-імпортного потенціалу підприємства / Н.К. Назаров, І.О. Бараннік // Бізнес-Інформ. - 2019. - №5. - C.142-149.

9.Паламарчук О.М. Сутність та формування організаційно-економічного механізму управління конкурентоспроможністю підприємства / О.М. Паламарчук // [Електронний ресурс]. - Режим доступу: http://archive.nbuv.gov.ua/portal/soc_gum/evu/2011_17_2/Palamarchuk.pdf.

10. Потенціал підприємства: формування та оцінка: Навчальний посібник / О.К. Добикіна, В.С. Рижиков, С.В. Касьянюк, М.С. Кокотько, Т.Д. Костенко, А.А. Герасимов. - К.: Центр учбової літератури, 2007. - 208 с.

\section{References:}

1.Vasylkivskyj D.M. (2014). Pidvyshhennya ekonomichnogo potencialu pidpryyemstva: teoriya, metody, praktyka : monografiya [The enterprise's economic potential increasing: theory, methods, practice]. Xmelnyczkyj: XNU. [in Ukrainian]

2.Dovgan L.Ye., Dudukalo G.O. (2012). Formuvannya organizacijno-ekonomichnogo mexanizmu efektyvnogo upravlinnya pidpryyemstvom [Formation of effective organizational and economic mechanism of an enterprise]. Available at: http://ela.kpi.ua/bitstream/123456789/2986/1/41.pdf. (accessed 11 september 2019). [in Ukrainian]

3. Kaletnik G.M., Zabolotnyj G.M., Kozlovskyi S.V. (2011). Innovacijni modeli upravlinnya strategichnym ekonomichnym potencialom suchasnykh ekonomichnykh system [Innovative models of managing the modern economic systems' economic potential]. Available at: https://www.researchgate.net/profile/Serhii_Kozlovskyi/publication/298002657_Innovative_models_of_strategic_economic_potential_ management_within_contemporary_economic_systems/links/5ca72b314585157bd3235acf/Innovative-models-of-strategic-economicpotential-management-within-contemporary-economic-systems.pdf. (accessed 10 september 2019). [in Ukrainian]

4. Karachyna N.P. (2010). Ekonomichna povedinka mashynobudivnyh pidpryyemstv: teoriya, metodologiya, prakty ka upravlinnya [Economic behavior of machine-building enterprises: theory, methodology, management practice]. Vinnycya: Knyga - Vega. [in Ukrainian]

5.Kendyukhov O.V. (2007). Organizacijno-ekonomichnyj mexanizm upravlinnya intelektualnym kapitalom pidpryyemstva [Organizational and economic mechanism of enterprise's intellectual capital management] (Doctorate degree Thesis). Donetsk: Institute of industrial economy of Ukraine's national academy of sciences [in Ukrainian]

6. Kozlovskyj S.V. (2010). Rol strategichnogo ekonomichnogo potencialu v upravlinni faktoramy rozvytku suchasnykh ekonomichnykh system [The role of strategic economic potential in managing the developing factors of modern economic systems]. Ekonomika ta derzhava. 2, 55-58. [in Ukrainian]

7. Krasnokutska N.S. (2004). Potencial pidpryyemstva: formuvannya ta ocinka [Enterprise's potential : formation and evaluation]. Xarkiv. [in Ukrainian]

8. Nazarov N.K. (2019). Ekonomichna bezpeka eksportno-importnogo potencialu pidpryyemstva [Economic safety of enterprise's export and import potential]. Biznes-Inform. 5, 142-149. [in Ukrainian]

9.Palamarchuk O.M. (2011). Sutnist ta formuvannya organizacijno-ekonomichnogo mekhanizmu upravlinnya konkurentospromozhnistyu pidpryyemstva [The essence and formation of organizational and economic mechanism of enterprise's competence management]. Available at: http://archive.nbuv.gov.ua/portal/soc_gum/evu/2011_17_2/Palamarchuk.pdf. (accessed 10 september 2019). [in Ukrainian]

10. Dobykina O.K., Ryzhykov V.S., Kasyanyuk S.V., Kokotko M.Ye., Kostenko T.D., Gerasymov A.A. Potencial pidpryyemstva: formuvannya ta ocinka [Enterprise`s potential: formation and evaluation]. K.: Centr uchbovoyi literatury. [in Ukrainian]

Рецензент д.е.н., професор Нижник В.М. 